\title{
Nordisk idrottspolitik i brytningstid \\ - Kritiska reflektioner från en svensk lokal horisont
}

Af Paul Sjöblom

Hur ser det lokala idrottslivet i en medelkommun ut idag? Bedriver idrottsföreningarna den typ av idrott som staten säger sig vilja ha? ${ }^{1}$ Vad kommer den nya idrottspolitiken, som jag nedan talar om, med försök till en hårdare kontroll och styrning av föreningsidrotten att medföra och vad kommer marknadsanpassningen av idrotten och tävlingsintensifieringen inom storklubbarna, med en tilltagande kommersialisering, professionalisering och specialisering, att innebära? Tar processerna möjligen ut varandra eller samverkar de och förstärker nya trender inom föreningsidrotten? Dessa frågeställningar arbetar jag med inom ramen för forskningsprojektet Svensk idrottsmodell $i$ upplösning, ett tvärvetenskapligt projekt där jag ansvarar för de delar som berör den kommunala nivån. ${ }^{2}$ I denna artikel presenteras några preliminära resultat och reflektioner från genomgångar av samtida forskning, kommunmaterial och officiellt tryck under åren 2000-2005. Det sker mot bakgrund av en historisk diskussion om välfärdsstatens förhållande till idrotten, delvis ur ett nordiskt perspektiv.

\section{Den nordiska idrottsmodellen}

Historikerna Johan R. Norberg och Niels Kayser Nielsen samt statsvetaren Bjarne Ibsen har på skilda håll hävdat att det finns stora likheter mellan de svenska, norska, danska, finländska och isländska - stats- korporativa - modellerna avseende förvaltningen av de allmänna, gemensamma medlen till idrotten. Enligt dem utgör den nordiska »særvejen« ett flagrant undantag, huvudsakligen beroende på att välfärdsstaterna i norr är de mest genomorganiserade i hela världen. ${ }^{3}$

Den frivilliga idrottsrörelsen har betraktats som samhällsnyttig, i betydelsen att den skapat mervärden som kommit hela samhället till godo. Den har förfogat över stor sakkunskap, en omfattande administrativ apparat och många medlemmar och därmed tilldelats en betydande roll i den fysiska och mentala fostran av »den gode medborgaren «. En bekräftelse på detta utgör det stora finansiella stödet. Ett annat belägg för frivilligidrottens starka position är den bibehållna, om än relativa, autonomin. Riksförbunden har bjudits in av staten att samverka kring utformandet av idrottspolitiken, en invitation som förbundsledningarna villigt accepterat då riktlinjerna om en idrott àt alla ansetts ligga helt i linje med de egna målsättningarna. Idrottshistorisk forskning i Sverige, Danmark och Norge visar enhälligt, att de utvalda organisationerna har fått fullt förtroende av parlamentarikerna att fördela medlen och leda idrottsrörelsen. Detta trots att allt fler kroppsövningsformer över tid efterfrågat utökade resurser och att Sveriges Riksidrottsförbund (RF), Norges Idrettsforbund (NIF), Danmarks Idræts-Forbund (DIF) 
och Danske Gymnastik og Idrætsforeninger (DGI) i flera fall gått hårt åt konkurrerande organisationer när hegemonin uppfattats som hotad. Den nordiska förvaltningsmodellen uppvisar, kort sagt, en märkvärdig stabilitet och kontinuitet. ${ }^{4}$

Hur ser konstruktionen för statens bidrag till idrotten ut idag? Skiljer sig Sverige, som jag specialstuderat, från övriga Norden?

\section{»Idrott åt alla«, den alltjämt överordnade men mångtydiga målsättningen för svensk idrottspolitik}

Enlig den idrottspolitiska policy som presenteras på regeringens hemsida är de övergripande målen och riktlinjerna för idrottspolitiken centrerade kring de tre grundstenarna hälsa, demokrati och god fritidssysselsättning: »För att främja en god folkhälsa ska samhället och skolorna uppmuntra och ge möjlighet för barn, ungdomar och vuxna att motionera och bedriva idrott«, heter det till exempel. Vidare ska idrottsrörelsen »bygga på ideellt engagemang och bedriva en verksamhet som värnar om god etik, lika förutsättningar för flickor och pojkar, kvinnor och män, arbetar aktivt för integration samt värnar om demokratisk fostran «. ${ }^{5}$ Att även Riksidrottsförbundet ställer upp på dessa formuleringar framgår klart och tydligt av dess främsta styrdokument Idrotten vill, antaget vid Riksidrottsmötet $1995 .{ }^{6}$

Officiellt sett är således den första statsmakten och RF helt eniga om hur en god idrott - en idrott åt alla - bör bedrivas. Det är mer tveksamt om man också är det när det gäller hur uppkomna problem ska behandlas och målen uppnås. Regeringens så kallade nya idrottspolitik, formulerad i propositionen En idrottspolitik för 2000talet från år 1999 och realiserad genom Handslaget, är kraftigt debatterad i RF:s officiella organ Svensk idrott. ${ }^{7}$ Statsråden och den högsta RF-ledningen verkar tämligen överens om att den svenska folkhälsan håller på att försämras dramatiskt, och att detta sker på samma gång som de ekonomiska skillnaderna ökar; alla har helt enkelt inte längre råd att idrotta. Men medan förbundet menar att lösningen på problemet ligger i mer resurser till en ännu friare idrottsrörelse så förespråkar regeringens företrädare tydligare mål och riktlinjer. Mer kontroll men också mer samverkan mellan idrottsrörelsen och det omgivande samhället. Enligt idrottsministern råder alltjämt samstämmighet i riksdagen om idrottens stora samhällsnytta, inkluderat elitidrotten. »Den nya politiken « (med mer öronmärkta medel, min anm.) ska bara uppfattas som ett sätt att värna idrottens folkrörelsebas; ett sätt att försöka bryta trenden mot ökade skillnader i samhället beträffande hälsa och tillgång på idrott. ${ }^{8}$ Möjligen kan detta också tolkas som att staten inte är helt nöjd med RF:s insatser. Förbundsordförandens kommentar är i fall talande för Riksidrottsförbundets sätt att oppfalla det hela: »Det handlar om en klar inskränkning $i$ idrottsrörelsens egna möjligheter att utveckla sin verksamhet $\ll .{ }^{9}$

Det räcker dock inte med löst grundade antaganden, menar jeg. Frågan om en hårdare styrd idrottspolitik, och, omvänt, om en minskad autonomi för RF, måste undersökas empiriskt, i synnerhet på den lokala nivån där idrottspolitiken implementeras och den faktiska idrottsutövningen äger rum. Bryr sig enskilda föreningsstyrelser överhuvudtaget om statens och moderförbundets krav i samband med resurstilldelning? Vilka verktyg har egentligen staten, på central och lokal nivå, för att styra 
idrottsföreningarnas verksamheter i önskad riktning? Hur stor är viljan att göra det? Klart är att RF numera frenetiskt värnar sin myndighetsroll; att man gör sitt yttersta för att leva upp till bilden av en samhällsnyttig folkrörelse. Undersökningar och resultat presenteras ofta och inte sällan försöker man också få landets kommuner att kommentera dessa. Vi kan anta att det åtminstone delvis sker för att visa upp enighet och inledd samverkan. ${ }^{10}$ Vad man dock framför allt tycks eftersträva i förhållandet till kommunerna är att säkra stödet på lång sikt, dels genom en samordning av strategier och argument med Kommunförbundet, dels genom att man tillsammans med kommunledningarna utarbetar övergripande idrottspolitiska handlingsprogram. ${ }^{11}$

Riksidrottsförbundets egna studier under åren 2000-2005 indikerar att kommuner väljer att prioritera näridrottsanläggningar, alternativa anläggningar och anläggningar för kvinnodominerade idrottsgrenar. För det andra att större idrottsevenemang ger positiva ekonomiska och sociala effekter, för det tredje att allt fler idrottsföreningar satsar på hälsa och lek istället för på prestation och allvar, och, för det fjärde, att det ideella inslaget fortfarande är mycket stort. Granskar man dessa undersökningar närmare slås man emellertid av att de vanligtvis är kraftigt begränsade och tveksamma ur jävsynpunkt (SISUIdrottsutbildarna är ju RF:s eget förlag). ${ }^{12}$ Resultaten ska dessutom ställas mot dem som bland andra idrottsprofessorerna Tomas Peterson och Lars-Magnus Engström producerat, vilka visar på en omfattande selektering i tidig ålder, bristande föreningsdemokrati och dåligt skötta finanser inom den svenska idrottsrörelsen. ${ }^{13}$

En viktig fråga i sammanhanget är också hur »idrott åt alla« ska tolkas. Ska man förstå det som att staten vill försöka få med så många som möjligt och samtidigt att så många som möjligt rör sig så mycket som möjligt? Det verkar rimligt med tanke på vad som ovan sagts. Detta kan dock innebära olika typer av satsningar, som till exempel en prioritering av vissa utvalda utövarkategorier, organiserade inom vissa kroppsövningsformer och föreningar, i en förhoppning om att folk har samma intressen som tidigare och att de organiserade utövarna vill röra sig mycket. Alternativt kan det innebära en prioritering av individer som tidigare visat litet intresse för idrott eller som av olika anledningar valt att sluta idrotta. Om det senare är fallet bör det rimligtvis innebära satsningar på alternativa organisationer och anläggningar, eftersom vi kan anta att ett huvudskäl till att de inaktiva varit just inaktiva är att de inte lockats av det befintliga utbudet. Om de nu alls är intresserade av att röra på sig, vill säga.

\section{Aktuella trender på det svenska lokalplanet}

År 2005 motsvarade det totala samhällsstödet till idrotten, allt enligt siffror framtagna av RF och Svenska kommunförbundet, uppskattningsvis 30 miljarder kronor. Den största delen, cirka 15 miljarder, kom från idrottsrörelsen själv i form av egenfinansiering genom ideellt arbete, försäljning, medlemsavgifter etc. Ungefär 12 miljarder kronor tillfördes via staten, varav kommunerna stod för lejonparten, cirka 8, medan 3 miljarder utgjordes av näringslivssponsring och Bingolotto. Tyngdpunkten i ekonomiskt stöd låg med andra ord på den offentliga och den informella sektorn. Endast en mindre del kom direkt från näringslivet $\mathrm{i}$ den kommersiella sektorn. ${ }^{14}$ Detta är en viktig iakttagelse och en central 
utgångspunkt när man diskuterar maktoch demokratifrågor inom idrotten. Var kommer resurserna ifrån och vilka krav och beroendeförhållanden för de med sig? ${ }^{15}$

Det kommunala stödet har fortsatt att hålla ungefär samma reella ökningstakt under början av 2000-talet som det gjorde innan neddragningarna på 1990-talet. Verksamhetsbidragen har skurits ned men detta har kompenserats av ett snabbt växande anläggningsstöd, där nyinvesteringar utgjort en betydande del. Parallellt har allt fler, även större och dyrare, anläggningar övergått i bland-, förenings- eller privat drift; en partiell avkommunalisering av anläggningsutbudet har ägt rum. Rent organisatoriskt har de flesta större kommuner fortsatt med sammanhållna kultur- och fritidssektorer medan de mindre valt andra typer av organisationer för sina kultur- och fritidsfrågor, oftast med fler verksamheter integrerade, till exempel utbildningsfrågor. I politiskt hänseende har övergången från en behovsbaserad och bidragsstyrd idrottspolitik till en efterfrågebaserad och allt mer ersättningsstyrd fortskridit, vilket bland annat har gestaltat sig i ett utökat kontraktsskrivande om drift- och underhåll av anläggningar. ${ }^{16}$

En rad intressanta trender kan också iakttas inom föreningslivet. Till exempel tycks allt fler klubbar, även lokala storklubbar, vilja profilera sig hårdare i riktning mot en mer hälsoinriktad motionsoch rekreationsidrott. ${ }^{17}$ Styrelserna säger sig ta avstånd från elitinriktad prestationsidrott före 13-14 års ålder. De upprättar handlingsstrategier och styrande policyprogram som understryker breddidrottens värde. Parallellt har också de traditionella fördelningsprinciperna kring de gemensamma föreningsresurserna börjat diskuteras på styrelsemötena, vilket tyder på att antingen nya värderingar tagit form, att maktpositionerna förskjutits mellan medlemsgrupperna, åtminstone inom vissa delar av idrottsrörelsen, och/eller att statens och RF:s inflytande har ökat. Alternativt handlar det om en nygammal taktik från styrelseledamöterna, som går ut på att visa upp en samhällsnyttig fasad gentemot kommun, näringsliv och allmänhet i syfte att säkra resurstillförseln. Jag konstaterar, att samtidigt som hälsoinriktningen fått en mer framskjuten placering, jämlikhetsfrågorna hamnat på dagordningen och selektering i tidig ålder ifrågasatts, så har prestationsfokuseringen inom junioridrotten tilltagit. Det gör frågan befogad: Vilka barn och ungdomar är egentligen välkomna till en verksamhet som i stort utgör en förberedelse för representationslagsspel? Här, precis som när det gäller de offentliga målen och medlen, måste empiriska data och inte teoretiska argument och svepande generaliseringar, som tyvärr ofta är fallet i dagens idrottsdebatt, utgöra grunden för diskussionen.

\section{Kommunens verklighet och prioriteringar: Fallet Norrtälje}

Mina fortsatta studier av Norrtälje kommun i Uppland, cirka åtta mil norr om Stockholm, av Statistiska centralbyrån kallad »genomsnittskommun «, visar inte helt oväntat på en komplex verklighet, där ett realpolitiskt medvetet kommunfullmäktige agerar mer pragmatiskt än regeringen på riksplanet.

I ekonomiskt hänseende står det klart att de allmänna besparingarna i Norrtälje också drabbar Kultur- och fritidsnämnden vid inledningen till 2000-talet, i synnerhet från och med 2003. ${ }^{18}$ Nämnden tvingas vara 


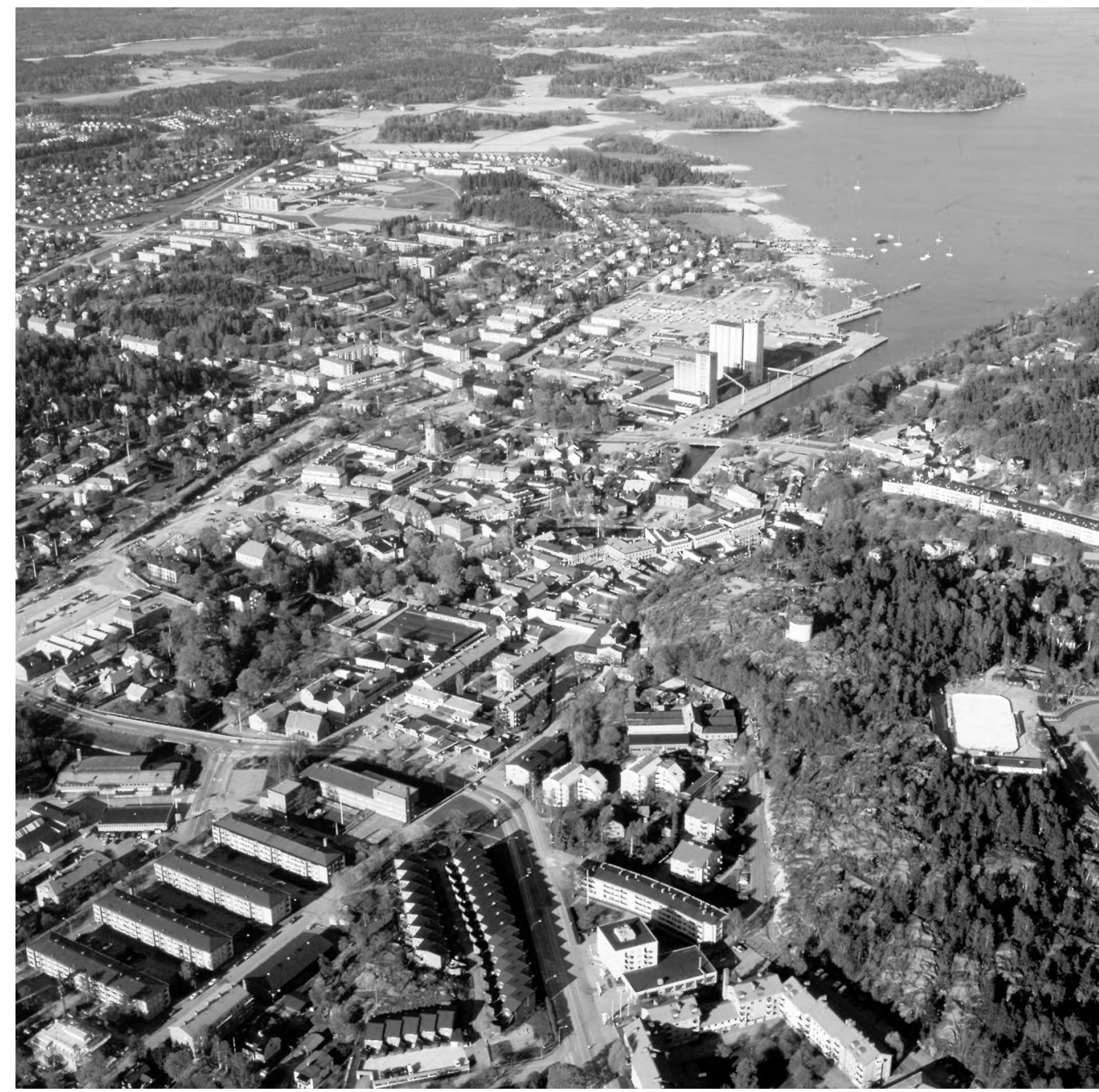

Norrtälje stad är administrativ huvudort i Norrtälje kommun, en medelstor kommun med drygt 50.000 invånare varav omkring 17.000 är bosatta i huvudorten. Inte mindre än 235 olika föreningar konkurrerar om invånarnas intresse och engagemang, kommunens allmänna fritidsmedel och företagens sponsorpengar (Fotograf: Avena J. Howard, Norrtälje kommun, Stadsarkivet).

mer restriktiv med anläggningsutbyggnaden, eller i alla fall hävdar man det. ${ }^{19} \mathrm{De}$ nyinvesteringar som genomförs är sedan länge inplanerade. Alternativt så genomförs de i samverkan med de lokala storklubbarna och företagen, eller så hänger de samman med större kommun- och närings- livsunderstödda evenemang i centralorten. I samtliga fall sker investeringarna i samma typ av anläggningar som tidigare. Det är de stora prestationsinriktade lagbollsporterna som i första hand får sina behov tillgodosedda. Och detta med mångmiljonbelopp. ${ }^{20}$ 


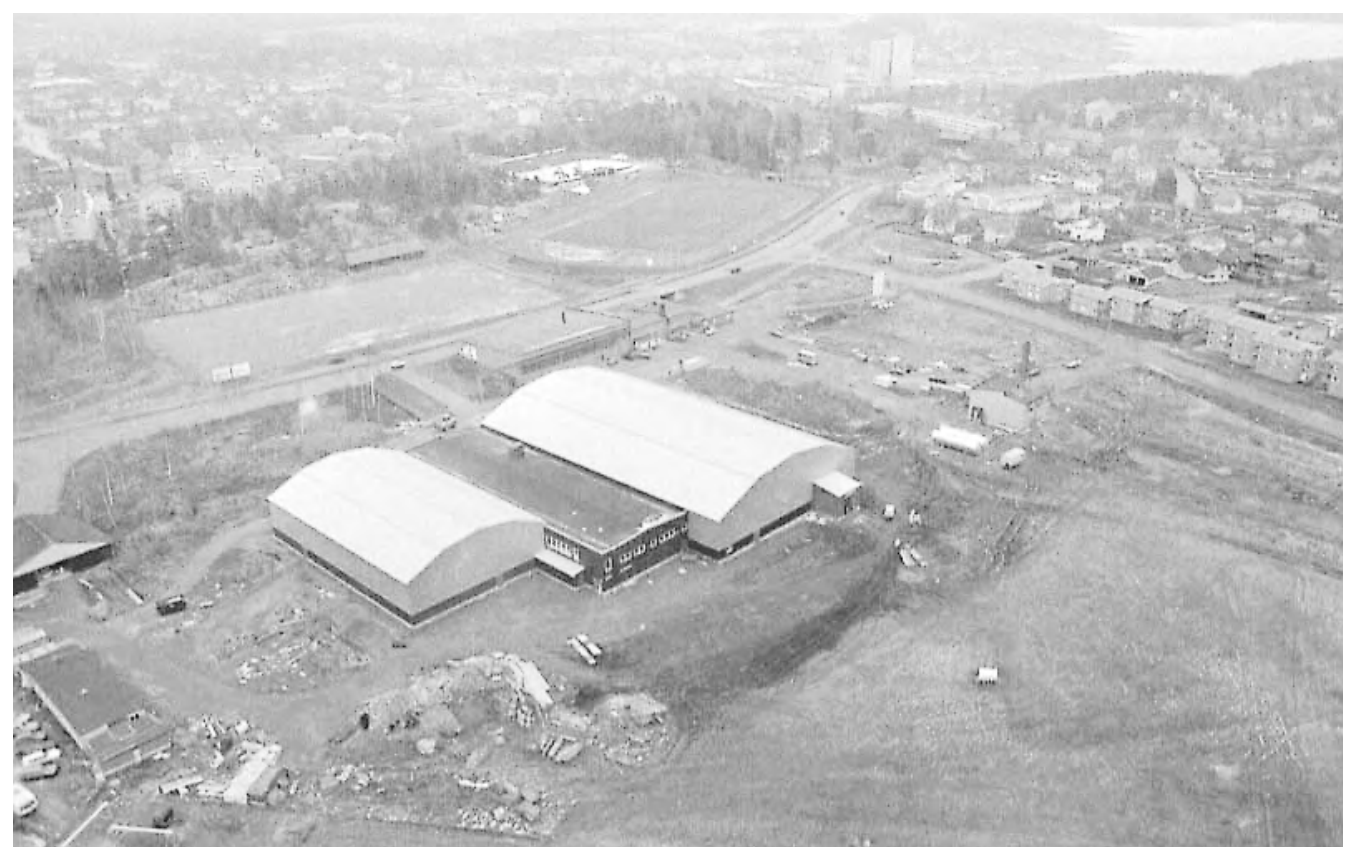

Idrottsparken utgör kärnan i Norrtälje Sportcentrum, Norrtälje stads centralanläggning för idrott. Anläggningen stod klar för invigning i mars 1988 men har sedan dess byggts om och byggts ut för åtskilliga miljoner kronor. Väger samhällsnyttan upp de reella kostnaderna? (Fotograf: Gösta Jansson, Norrtälje Bild).

Överhuvudtaget är det så att PR-aspekten, det vill säga marknadsföringen av kommunen, blivit allt viktigare för Norrtäljepolitikerna, oavsett ideologi, och att detta är något som tydligt gynnar idrotten. Inför Svenska mästerskapen i friidrott plöjs omkring fyra miljoner kronor ned i underhåll, utbyggnad och reparationer av centralanläggningen Idrottsparken, vilket senare visar sig bli fem miljoner kronor då budgeten kraftigt överskrids. Den årligt återkommande Mästarcupen i ishockey, liksom Rånäs $4 \mathrm{H}$ :s friidrottsskola för ungdomar och föreningens arrangemang av den så kallade Norrtäljegalan, kräver mindre investeringar men däremot större verksamhetsbidrag på mellan 50. och 100.000 kronor/år. I kombination med de ständiga reinvesteringarna för att säkra driften av de större, numera slitna idrottsplatserna och de växande energikostnaderna för konstfrusna bandybanor och hockeyrinkar, bidrar satsningarna till att ackumulera ett årligt nettounderskott i driftsbudgeten för idrotts- och friluftsanläggningar på flera hundra tusen kronor. Underskottet måste täckas via omdisponering från andra kultur- och fritidskonton. Det är ett problem som kommunen tycks vara fullt medveten om. »Investeringar får därmed större betydelse eftersom framtida och höga energikostnader måste vägas mot potentiella besparingar «, står det att läsa i 2003 års verksamhetsberättelse. Där står även att idrottens positiva effekter på folkhälsan har lett till »ett förslag till idrottspolitiskt handlingsprogram, med folkhälsoaspekten i förgrunden $[. ..] \ll .{ }^{21}$ Är Norrtälje kommun 
i färd med att förändra den sedan länge fastlagda politiken? Tveksamt, blir svaret, om man studerar den ekonomiska långtidsplaneringen.

Vid ingången till det nya millenniet gäller alltjämt en fördelningsmodell som utgår från idén om fostrande barn- och ungdomsverksamhet och premierande av tidigare eftersatta grupper, såsom kvinnor (i förhållande till män), pensionärer, arbetslösa, invandrare och »alternatividrottare «. Enda skillnaden mot 70-, 80- och 90-talen tycks vara att kommunen har blivit tydligare i sina principiella ställningstaganden, att verksamhetsbidragen blivit mer reglerade och att uppföljning och kontroll framhålls som något viktigt. I realiteten är det fortfarande höga medlemstal och hög aktivitetsfrekvens som huvudsakligen styr fördelningen av de gemensamma idrottsresurserna, vilket innebär att det är de stora lagbollsportsföreningarna, bestående av många elitsatsande unga män, som får mest. Jag noterar också, att samtidigt som fler bidrag fått klarare målformuleringar så har ett nytt så kallat utvecklingsbidrag tillkommit, som tillåter Kultur- och fritidsnämnden att årligen dela ut miljonbelopp efter eget gottfinnande. Nämnden initierar en rad utredningar, till exempel om hur en eventuell fotbollshall »kan påverka föreningslivet, näringslivet och turismen $i$ Norrtälje kommun«, om hur fördelningen av kultur- och fritidsnämndens budget ser ut och om vilka fritidsaktiviteter som finns i kommunen. Men någon resultatredovisning från dessa utredningar finner jag inte, och tydliga markeringar mot de föreningar som inte följer vad man i förhandlingar med kommunen åtagit sig, något tjänstemännen på Kultur- och fritidsförvaltningen efterfrågar flera gånger, har jag bara funnit vid ett enda tillfälle. ${ }^{22}$ Detta talar för forekömsten av en dold idrottspolitisk agenda.
I viss mån kan man ändå tala om ett nytänkande. Bara det faktum att så många utredningar överhuvudtaget initieras är någonting fullständigt nytt. Att dessa nu dessutom ställer nya typer av frågor visar på ett fördelningspolitiskt intresse, på en ökad medvetenhet hos utredarna om att de idrottspolitiska besluten och icke-besluten inte bara påverkar de idrottsintresserade utan hela lokalsamhället.

\section{Idrottsföreningens verklighet och prioriteringar: Fallet $B K$ Vargarna}

Ur ett föreningsperspektiv, närmare bestämt Bollklubben Vargarnas, Norrtälje stads dominerande förening alla kategorier och med fotboll som huvudsysselsättning, kan konstateras, att de processer som präglade idrottsföreningen och dess kultur under perioden 1970-1999, en pågående marknadsanpassning och tävlingsintensifiering, blivit än påtagligare under början av 2000-talet. De sätter tydliga avtryck i samtliga verksamheter.

Vargarna är tveklöst att betrakta som en storklubb med lokala mått mätt. Cirka 1 200 medlemmar, varav 500 är under 12 år, och en årsomsättning på 3-4 miljoner kronor talar sitt tydliga språk. Det är också en förening med stora ekonomiska problem. Sammantagna utgör de offentliga bidragen och ersättningarna fortfarande den största intäkten medan den avlönade personalen utgör den största kostnaden. Differensen dem emellan ökar dock över tid. Rörelseresultaten försämras från år till år. Låneskulden växer. ${ }^{23}$ Även den kraftiga nedgången för Bingolotto utgör ett stort avbräck på intäktssidan, som måste kompenseras med mer sponsorinkomster och ökade aktivitets-/deltagaravgifter samt krav på hårda- 
re ideella tag. ${ }^{24}$ Varje lag »ska förmås « sälja 15 bingolotter var per vecka. Varje barn- och ungdomsspelare ska tilldelas två Sportkalendrar var, »som han/hon bör sälja«. Expansionsivern är, kort sagt, stor, vilket även markeras av anlitandet av diverse konsulenter för att »nå ett förbättrat resultat i framtiden «. Allmänt sett handlar det allt som oftast om att öka inkomsterna för BK Vargarna, mer sällan om att minska utgifterna, trots ledningens tal om vikten av att se över kostnadsutvecklingen. ${ }^{25}$ Den tydligare lek- och hälsoinriktning, som styrelsen propagerar för i sina policy- och handlingsprogram, märks också lite av, desto mer av den tilltagande elitiseringen bland juniorer (13-16 år). Flera omfattande och dyra så kallade talangutvecklingsprogram drivs parallellt. Det blir många träningsläger, resor och matcher för de utvalda spelarna och ledarna. Ett par styrelseledamöter ges, intressant nog, i uppdrag att undersöka varför vissa lags kostnader är så mycket högre än andras - och varför så många juniorer väljer att sluta. ${ }^{26}$

Föreningsdemokratiska frågor, som kan kopplas till tävlingsintensifieringen, hamnar även i fokus då klubben tackar nej till att anordna en kommunal cup för flickor samtidigt som man anordnar en för pojkar, och när flera lag klagar högljutt över att de inte ges tillfälle att träna och spela på det nya konstgräset på grund av representations- och juniorelitlagens alla uppbokningar. Vidare när damernas A-lag, som befinner sig i en högre division än herrarnas, av klubbledningen inte tillåts spela sina seriematcher på hemmaarenan Idrottsparken med hänvisning till Fotbollförbundets prioriteringsordning (1. Herrlag 2. Juniorlag 3. Damlag), och då inkomsterna från barn- och ungdomslagens försäljning av diverse lotter med mera utan vidare motivering går till finansieringen av herr- lagens träningsläger. Då bör emellertid tilläggas, att det är mycket få Vargar som bevistar de allmänna medlemsmötena. Ännu färre som uttrycker sina åsikter. ${ }^{27}$ Ska man tolka detta som att de flesta medlemmar och anhöriga föräldrar är nöjda med föreningens verksamheter och prioriteringar? Eller ska man läsa av det som att många helt enkelt inte bryr sig? Orkar man inte bry sig, är man rädd för att bry sig, eller tror man helt enkelt att det inte spelar någon roll om man ifrågasätter styrelsens policy?

Som ett led i marknadsanpassningen, för att skapa bättre ekonomiska villkor, arbetar Vargstyrelsen hårt för att få till stånd nya sponsoravtal. Samtidigt vårdar man ömt förhållandet till de politiska makthavarna. Det är förståeligt med tanke på att kommunen totalt sett fortfarande står för den största resurstillförseln vid sidan om föreningsmedlemmarnas egeninsatser. Faktum är att den lokala storklubbens relation till den lokala myndigheten är mer nära än någonsin tidigare. Styrelsen har mängder med sammanträden med de kultur- och fritidsansvariga, vilka inte sällan leder till önskvärda resultat betraktat med vargögon. Inomhustiderna blir fler och bättre i tidshänseende, därtill mer sammanhängande och placerade i kommunens större hallar. År 2005 blir »Norrtälje kommun« till och med en fast punkt på föreningsstyrelsens dagordning, under vilken begreppet »bearbeta« inte sällan förekommer i vokabulären när styrelseledamöter instrueras att vara drivande i för Vargarna avgörande frågor. Klubbledningen tycks veta exakt vilka makthavare man ska vända sig till, strategierna är minst sagt genomtänkta. ${ }^{28}$ Jag undrar hur många andra ideella organisationer som är lika politiskt medvetna och drivna som idrottsrörelsen? En annan fundering rör hur staten ska agera för att leva 


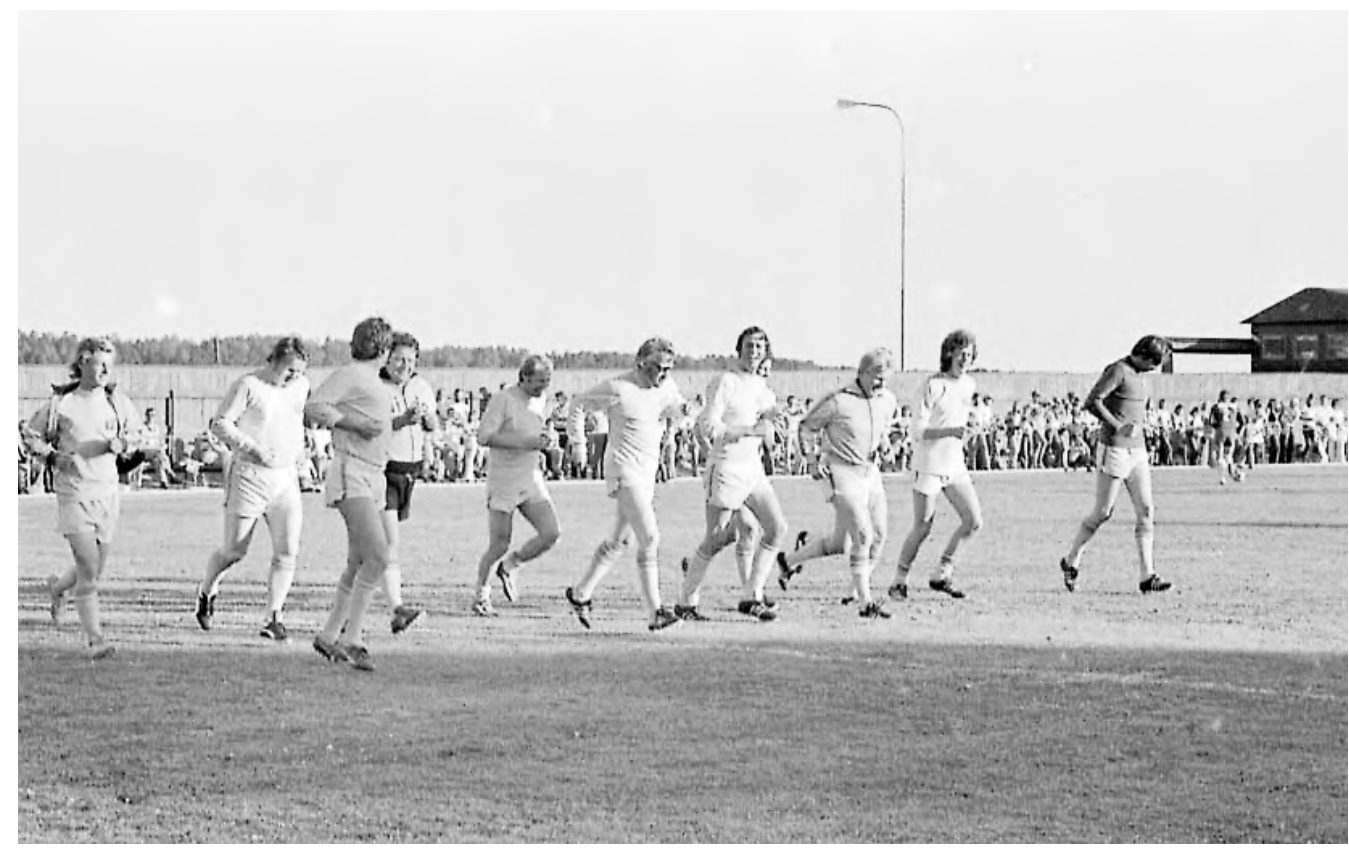

Kommungubbar spelar fotboll. Relationen mellan den lokala storklubben BK Vargarna och politikerna i Norrtälje har länge varit god, men aldrig tidigare så nära som nu under början av 2000-talet. Beroendet är ömsesidigt - PR för kommunen och barn- och ungdomsfostran i utbyte mot stor offentlig resurstillförsel (Fotograf: Gösta Jansson, Norrtälje Bild).

upp till mottot om en idrott åt alla, med tanke på storklubbarnas lobbyintensiv? Ett första steg torde väl vara att skaffa sig en bra överblick över vilka verksamheter som bedrivs på gräsrotsnivå, över vilka värdegrunder som styr inom olika föreningskulturer. Har man tagit detta steg?

\section{Nordisk idrottsforskning påvisar gemensamma problem}

Resultaten från mina fortsatta undersökningar av kommunal idrottspolitik i Sverige 2000-2005 visar, att de allmänna och gemensamma fritidsresurserna i stor utsträckning har fortsatt att tillfalla den organiserade föreningsidrotten. Detta med den huvudsakliga motiveringen att den är samhällsnyttig. Vidare har framkommit att det framför allt är respektive lokalsamhälles manligt dominerande och prestationsinriktade storklubb, med populära lagbollsporter som huvudsysselsättning, som ofta dragit vinstlotten. Detta har i mycket liten utsträckning sin grund i rent idrottsliga överväganden, snarare är det kommunens makthavares uppfattningar om vem som har varit bäst lämpad att bidra till samhällets ekonomiska tillväxt och välstånd som blivit avgörande. Strukturerna har visat sig vara ytterst stabila (eller stela, om man så vill). Tidigare fastlagda fördelningsprinciper ligger i princip fast. Nätverken som främjar prestationssatsningarna består.

Systemstabiliteten (eller rigiditeten) ver- 
kar gälla i hela Skandinavien, och på både riksnivå och kommunal nivå. Det indikerar de senaste årens forskning kring statens försök med riktade satsningar. Handslaget mellan regeringen och den svenska idrottsrörelsen, som ger idrotten 250 miljoner kronor mer per år under perioden 20032006, utöver det ordinarie statsanslaget, markerar tydligt Riksidrottsförbundets förnyade förtroende för att administrera statsmakternas bidrag till idrotten och agera $\mathrm{i}$ idrottsrörelsens ledning. RF, som till en början reagerade starkt på dessa, som man uppfattade det, styrda bidrag, har efterhand ställt sig mer positivt till storsatsningen. Utvärderingen av projektet pågår för fullt, och det är riksförbundet som fă tt i uppdrag att ta hand om den. Förbundet ska alltså återigen - utreda sin egen verksamhet, och detta med motiveringen att man sitter inne med sakkunskapen. Frågan om vikten av oberoende granskare tycks aldrig ha ställts. Det verkar den inte heller ha gjort i Danmark.

Åren 1999-2002 genomfördes Idrætspolitisk idéprogram, IPIP, i Danmark med den uttalade målsättningen, att via en tredje instans, ett från både Kulturministeriet och idrottsrörelsen fristående organ, främja anläggningsdifferentiering och aktivitetsmångfald. ${ }^{29} \mathrm{I}$ sin omfattande utvärdering av projektet slår Bjarne Ibsen emellertid fast, att det kan ifrågasättas om målen har uppfyllts eller ens är på väg att göra det. IPIP har bidragit till nätverksbyggande, nya typer av samarbeten och ett antal nya anläggningar för spontanidrott. Men samtidigt, understryker Ibsen, är dessa nyvinningar sårbara eftersom deras överlevnad är helt avhängig en fortsatt resurstillförsel och ett fortsatt intresse från dem som leder, deltar i och utvecklar verksamheterna. Han visar med önskvärd tydlighet att det är de etablerade riksorganisationerna som i för- sta hand har främjats av statsmakternas satsning. Både Danmarks Idræts-Forbund och Danske Gymnastik og Idrætsforeninger har fortsatt att effektivt hävda sin autonomi och sin rätt till att agera central fördelningsinstans, också när det gällt IPIPmedel. De har motsatt sig varje form av statlig involvering samtidigt som de hävdat att de utgör garant för idrottens mångfald. Officiell statistik visar dock att det är få mindre idrotter och tidigare eftersatta utövargrupper som har premierats i praktiken. ${ }^{30}$ Summa summarum: Inom de befintliga maktstrukturerna har det visat sig vara mycket svårt att stödja alternativa projekt. Nytänkandet stannar vid tröskeln - pluraliseringen av idrotten uteblir.

Även Eivind Å. Skille, som undersökt det i Norge uppmärksammade Storbyprojektet, framhåller det nationella idrottsförbundets totala dominans. Storbyprojektet kan jämföras med det svenska Handslaget och det danska IPIP, då syftet är att med hjälp av centralstatliga medel göra fler medborgare fysiskt aktiva. Liksom i grannländerna administreras de extra bidragsmedlen av den största riksorganisationen, det vill säga Norges Idrettsforbund. Intressant nog, visar Skille, ledde projektet omgående i början av 2000-talet till att regeringen identifierade ett centralt dilemma: Det rådde en tydlig motsättning mellan prestationsinriktade och mer hälsoinriktade aktiviteter inom lokalidrotten, och de förstnämnda fick också klart mer resurser tilldelade sig. Flera förslag kom på förändringar, men inga åtgärder vidtogs. Varför? Ja, enligt regeringen ledde projektet till att antalet idrottsaktiviteter blev fler och till att NIF kunde fördjupa sina relationer till de lokala myndigheterna (läs säkra ett framtida stöd). Det var det viktiga. Aktivitet, konkluderar Skille, rangordnades före mångfald. ${ }^{31}$ 


\section{Ett historiskt brytningsskede}

Jag menar att vi just nu befinner oss mitt inne i ett intressant historiskt brytningsskede, där generella samhälleliga pluraliserings-, marknads- och demokratiseringsprocesser präglar ett allt mer mångfasetterat men samtidigt också mer specialiserat, politiserat och, därmed, motsättningsfyllt idrottsfält. Parallellt med att delar av idrottsrörelsen professionaliseras och kommersialiseras, även långt ner i seriesystemen, tar en ny överordnad idrottspolitik form, som är mer formaliserad och därmed mindre godtycklig. Dess målsättning är bland annat att fördela mer öronmärkta medel till tidigare försummade samhällsgrupper. Samtidigt leder marknadstänkandet och specialiseringstendenserna inom idrotten till nya alliansbildningar såväl inom som utom de etablerade förbunden och till tillkomsten av nya starka aktörer med nya särintressen, vilket medför nya påtryckningar i samband med anläggningsuppföranden, kontraktskrivanden och medelstilldelning.

Spänningarna inom de överordnade styrsystemen är i flera fall påtagliga. De kan möjligen sammanfattas enligt följande: Riksorganisationerna har att leva upp till kraven från de egna specialförbunden och föreningsmedlemmarna på mer specialisering och ökade resurser och från sponsorerna på mer elitidrott samtidigt som man ska tillgodose statens och allmänhetens krav på mer mångfald, mindre konkurrens och mindre kommersialisering till förmån för mer hälsa, demokratisk fostran och ideellt engagemang. Det är en, minst sagt, svårlöst ekvation. Man kan undra om den överhuvudtaget går att lösa inom en och samma organisationsmodell? I Norge, till exempel, växer specialförbundsfloran inom Norges Idrettsforbund parallellt med att idrottsföreningarna i allmänhet blir mer specialiserade. På samma gång expanderar idrottsrörelsen utanför NIF med allt fler förbund, vilka ofta representerar alternativa kroppsövningsformer såsom gymkedjan S.A.T.S. och Friskis \& Svettis. Detta leder till ökade spänningar mellan breddidrotten och elitidrotten. ${ }^{32}$ I Sverige är motsättningarna inte lika tydliga, men de finns där och deras grundorsaker liknar de norska. För stora specialidrottsförbund såsom Fotbollförbundet och Ishockeyförbundet står tillväxtfrågorna helt i centrum. Båda förbunden har genomgått påtagliga professionaliseringsprocesser under de senaste decennierna och marknadsanpassat sina verksamheter ända ned på gräsrotsnivå. Det har lett till att deras självbilder idag är föga representativa för det ideella folkrörelseideal som RF framhåller i Idrotten vill. Det är överhuvudtaget svårt att se att de värden som stora publik- och sponsortilldragande grenar genererar är desamma som skapas inom små, bidrags- och medlemsavgiftsberoende verksamheter som draghundssport, orientering, frisbee och varpa. Studerar man vidare det Akademiska idrottsförbundets, Skolidrottsförbundets och Gymnastikförbundets hälsoinriktade satsningar, så kan man konstatera att dessa inte ryms inom samma sfär som den prestationsinriktade och kommersiella idrott som bedrivs för seniorer och juniorer inom fotbolls- och hockeyförbunden. ${ }^{33}$ Men mer forskning krävs för att bilden ska klarna.

Sammanfattningsvis vet vi ännu så länge ganska lite om vad centralstaternas och kommunernas agerande under 2000-talet har gett för reella utslag, det vill säga hur de nya anläggningsutbyggnads-, bidrags- och ersättningsmodellerna kommer att påverka det lokala föreningslivets utseende i konkurrens med marknadskrafternas allt mer 
påtagliga inflytande. Vad vi med säkerhet kan säga är endast att en betydande del av makten, med tanke på de offentliga bidragens alltjämt stora omfattning, kommer att ligga hos dem som vinner tolkningsföreträde till »idrott åt alla« och som kan vara med och bestämma över vad som ska betraktas som en »god och samhällsnyttig idrott«.

\section{Noter}

1. Statsbegreppet i denna text omfattar både centralstaten - riksdagen och regeringen - och lokalstaten i form av primärkommunerna.

2. Frågeställningarna är formulerade utifrån resultaten i min avhandling. Se vidare Sjöblom P. (2006) kap.11.

3. Ibsen B. (2002a); Nielsen N K. (2002); Norberg R. J. (1997).

4. Goksøyr M, Andersen E \& Asdal K. (1996); Mortensen M. (2004); Norberg R. J. (2004); Trangbæk E. (1995).

5. http://www.regeringen.se/sb/d/1607/a/12403 (9/6 2005).

6. Idrotten vill (1996).

7. Via Handslaget har statsmakterna förbundit sig att under mandatperioden 2003-2006 tillföra idrotten ett extrastöd på totalt en miljard kronor. Detta med villkoret att idrotten arbetar i enlighet med uppdragna riktlinjer kring jämställdhet, etnisk mångfald och antidopning. Pengarna fördelas via RF, som också ansvarar för utvärdering av projektet.

8. Svensk idrott nr. 2 2000, s. 16, nr. 9 2005, s. 16-17.

9. Svensk idrott nr. 2 2000, s. 16, nr. 11 2000, s. 1, nr. 12 2000, s. 12-13, nr. 9 2005, s. 5.

10. Fritid \& park i Sverige nr.4 2004, s. 15; Svensk idrott nr. 7-8 2003, s. 4.

11. Sjöblom P. (2006) kap. 2, 5, 8; Svensk idrott nr. 12 2000, s. 14, nr. 11 2001, s. 29, nr. 6 2004, s. 1618, nr.6 2005, s. 5, nr. 7-8 2005, s. 5.

12. Fritid \& kultur i Sverige nr. 5 2001, s. 18; Fritid \& park i Sverige nr.1 2003, s. 24-25, nr. 3 2003, s. 12, nr. 4 2004, s. 14; Svensk idrott nr. 1 2002, s. 10, nr. 6 2002, s. 22-24, nr. 10 2002, s. 12-15, nr. 6 2003, s. $16-17$, nr. 10 2003, s. 10 , 13-15, nr. 11 2003, s. 30-31, nr. 2 2004, s. 13-15, nr. 4 2004, s. 20-23, nr. 6 2005, s. 10-12, nr. 1 2006, s. 4, 28.

13. Engström L-M \& Redelius K. (2002); Peterson T. (2002).

14. http://www.rf.se/t3.asp?p=14549; http://www.skl. se/artikel.asp? $\mathrm{A}=1095 \& \mathrm{C}=4055 \&$ Article Version $=22(30 / 2$ 2006).
15. Sjöblom P. (2006) s. 82-83, 498-503.

16. Ibid, s. 489-498.

17. Ibid, s. 461-467.

18. Årsredovisning Norrtälje kommun, 2000-2005.

19. Styrelsemöte $30 / 3 \quad 2000 \quad \S 35,20 / 2 \quad 2003 \quad \S 15$, 13/11 2003, 16/12 $2004 \S 123$, Kultur- och fritidsnämnden, Norrtälje.

20. Styrelsemöte 24/2 $2000 \S 5,30 / 32000 \S 40,1 / 2$ $2001 \S 14,1 / 22001 \S 18,22 / 32001 \S 40,5 / 52004$ $\S 44,15 / 62000 \S 72$, Kultur- och fritidsnämnden, Norrtälje.

21. Styrelsemöte 4/5 $2000 \S 55,15 / 62000 \S 87,5 / 5$ $2004 \S 45,19 / 52005 \S 1,14 / 22002 \S 12,19 / 5$ $2005 \S 65$, Kultur- och fritidsnämnden, Norrtälje; Verksamhetsberättelse Bokslut, Kultur- och fritidsnämnden, Norrtälje, 2000-2005.

22. Styrelsemöte 4/5 $2000 \$ 59,14 / 122000 \S 145$, $13 / 122001 \S 153,14 / 22002 \S 5,7 / 112002 \S 105$, $16 / 122004 \S 124,1 / 22001 \S 22,4 / 62002 \S 72$, $7 / 112002 \S 112,12 / 122002 \S 129,25 / 52004 \S 63$, 18/11 $2004 \S 113$, Kultur- och fritidsnämnden, Norrtälje; Utredning om fördelning av kultur- och fritidsnämndens budget, Kultur- och fritidsnämnden, Norrtälje, 2001.

23. Verksamhetsberättelser 2000-2005, BKV, Norrtälje.

24. Klubben hade sponsoravtal med inte mindre än 49 lokala företag år 2000.

25. Styrelsemöte 11/1 $2001 \S 13,16,4 / 22000 \S 12$, $15,28 / 22000 \S 6,24 / 62002$ §8, 28/8 $2002 \S 11$, $14 / 12003 \S 11,13 / 82003 \S 9,27 / 12004 \S 7,25 / 3$ $2004 \S 13,19 / 42004 \S 6,13 / 102004 \S 13$, »Hur mycket kostar ett ungdomslag...« 2003-11-20, BKV, Norrtälje.

26. Styrelsemöte 11/1 2000 \$7, 3/4 $2000 \S 11,30 / 6$ $2000 \S 9,12,15 / 82000 \S 9,26 / 22001 \S 13,1 / 10$ $2001 \S 10,30 / 102001 \S 10,12 / 112002 \S 16,29 / 4$ $2003 \S 6,18 / 102003 \S 10$, Årsmöte 2/5 $2001 \S 5$, »Fråga till BKV-Norrtäljes styrelse « 2000-05-29, »Projektbeskrivning Spelarutveckling...« 200101-18, »Avsiktsförklaring... « 2001-01-22, »BKV Norrtälje På väg framåt...2005«, s.3, 10, 13, 
»BKV Norrtälje Verksamhetsplan 2005«, s.13, 18, »Stadgar för BK Vargarna Norrtälje«, BKV, Norrtälje.

27. Styrelsemöte 28/2 $2000 \S 13,30 / 62000 \S 12,12 / 9$ $2000 \S 15,6 / 82001 \S 13,12 / 112002 \S 15$, Årsmöte 8/3 $2000 \S 19$, BKV, Norrtälje.

28. Styrelsemöte 19/1 2005 §6, 16/2 $2005 \S 6,13 / 4$ $2005 \S 8, \mathrm{BKV}$, Norrtälje.

\section{Referenser}

Bergsgard N A \& Rommetvedt H. När idrett og politikk kolliderer: Feilskjar eller systemendring?. På: www.idrottsforum.org 060517.

Bergsgard N A. Idrettspolitikkens maktspill. Endring og stabilitet $i$ den idrettspolitiske styrningsmodellen (Oslo, 2005).

Bøje C. Idratens tredje vej. Om idraten i kulturpolitiken (Århus, 1994).

Eichberg H. Body Cultures. Essays on Sport, Space and Identity (London/New York, 1998).

Engström L-M \& Redelius K (red.) Pedagogiska perspektiv på idrott (Stockholm, 2002).

Fritid \& Kultur i Sverige, 2000-2002 (Stockholm, 2000-2002).

Fritid \& Park i Sverige, 2003-2005 (Stockholm, 2003-2005).

Goksøyr M, Andersen E \& Asdal K. (red.) Kropp, kultur og tippekamp. Statens idrettskontor, STUI og idrettsavdelningen 1946-1996 (Oslo, 1996).

Ibsen B. En eller flere idratsorganisationer - hvorfor forskelle mellem de nordiske lande?. I: Eichberg $\mathrm{H}$ \& Vestergård Madsen B (red.) Idrætens enhed eller mangfoldighed (Århus, 2002a).

Ibsen B. Evaluering af Det Idratspolitiske Ideprogram (København, 2002b).

Idrotten vill - verksamhetsidé och riktlinjer för idrottsrörelsen in i 2000-talet (Farsta, 1996).

Mortensen M. Idrat som kommunal velfard. Mentalitet, velfærd og idratspolitik $i$ Kobenhavn, Ballerup og Skive 1870-1970 (København, 2004).

Mortensen M. Idrat som socialt kit (København, 2002).

Nielsen N K. Idrat og lokalhistorie - pejlinger og perspektiver $i$ en dansk og nordisk kontekst. Idrætshistorisk årbog 2002 (Viborg, 2003).

Norberg R. J. Idrottens väg till folkhemmet. Studier $i$ statlig idrottspolitik 1913-1970 (Stockholm, 2004).

Norberg R. J. A Mutual Dependency: Nordic Sports
29. Mortensen M. (2002).

30. Ibsen B. (2002b).

31. Skille A. E. (2006).

32. Bergsgard N A. (2005); Bergsgard N A \& Rommetvedt H. (2006); Skirstad B. (2002).

33. Sandahl B \& Sjöblom P. (2004).

Organizations and the State. The International Journal of the History of Sport 1997 (3).

Peterson T. Är idrottsrörelsen till bara för vissa?. Svensk idrott 2002 (11).

Protokoll m.m. BKV, Norrtälje 2000-2005, Norrtälje Sportcentrum.

Protokoll m.m. Kultur- och fritidsnämnden 20002005, Norrtälje Kommun.

Sandahl B \& Sjöblom P. Idrottsrörelse med identitetsproblem?. Svensk idrottsforskning 2004 (2).

Selle P. Idretten og det offentlege: Ein familie?. I: Klausen K K \& Selle P (red.) Frivillig organisering i Norden (Oslo, 1995).

Sjöblom P. Den institutionaliserade tävlingsidrotten. Kommuner, idrott och politik $i$ Sverige under 1900talet (Stockholm, 2006).

Sjöblom P. Hjälper det att tvivla på tävlingsidrotten? I: Idrott, historia och samhälle 2003 (Karlshamn, 2003).

Skille Å. E. Idrett for alle: Enhetlig mangfold eller en tredie vej?. På: www.idrottsforum.org 06.

Skirstad B. Norske idrettslag: Oversikt og utfordringer. I: Seippel $\varnothing$ (red.) Idrettens bevegelser: Sociologiske studier av idrett i et moderne samfunn (Oslo, 2002).

Svensk idrott, 2000-2005 (Farsta, 2000-2005).

Trangbæk E (koord.) Dansk idrætsliv. Velfard og fritid 1940-96, Bd 2 (Köpenhamn, 1995).

Utredning om fördelning av kultur- och fritidsnämndens budget. Rapport utgiven av Kultur- och fritidsnämnden, Norrtälje (Norrtälje, 2001).

Verksamhetsberättelse Bokslut. Serie utgiven av Kultur- och fritidsnämnden, Norrtälje, 2000-2005 (Norrtälje, 2000-2005).

Årsredovisning Norrtälje kommun. Serie utgiven av Norrtälje kommun, 2000-2005 (Norrtälje, 20002005). 
